International Journal of Instruction e-ISSN: 1308-1470 • www.e-iji.net

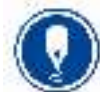

January $2021 \bullet$ Vol.14, No.1

p-ISSN: 1694-609X

pp. $867-888$

Article submission code:

20200324074719

Received: 24/03/2020

Revision: 06/08/2020
Accepted: 27/08/2020

OnlineFirst: $28 / 11 / 2020$

\title{
A Comparative Study of Stance and Engagement Used by English and Thai Speakers in English Argumentative Essays
}

Papitchaya Papangkorn

Language Institute, Thammasat University, Thailand, papitchayapapangkorn@gmail.com

Supakorn Phoocharoensil

Assoc. Prof. Dr., Language Institute, Thammasat University, Thailand, supakorn.p@litu.tu.ac.th

The present study aimed at investigating the similarities and differences of interactional metadiscourse markers and 3-word and 4-word participant-oriented bundles used in English argumentative texts of native speakers of English (NATIVE) and L1 Thai speakers (THAI) through the use of AntConc. The findings revealed that stance resources were used more often in THAI. The differences in the frequencies of hedges and attitude markers between the two corpora were significant, but this was not the case for boosters and self-mentions. Fewer hedges but more self-mentions, attitude markers and boosters were used by Thai learners than native speakers. Regarding engagement markers, a significant difference of the use of reader references and directives was evident in THAI, but there were significant differences in the use of questions, appeals to shared knowledge, and personal asides. For stance bundles and engagement bundles, although the number of the overall stance bundles found in NATIVE was lower than in THAI, there was lesser variety in the use of stance bundles in THAI. With respect to the structural patterns, both groups were similar, albeit with differences in terms of frequency. The findings of the study could shed light on interactional metadiscourse patterns and norms, and thus be beneficial for EFL stakeholders such as learners and teachers.

Keywords: interactional metadiscourse, corpus-based study, corpus-driven study, participant-oriented bundles, argumentative writing

\section{INTRODUCTION}

Metadiscourse markers are essential in argumentative writing because it is necessary for writers to make clear and understandable claims for readers and engage them in argument (Hyland, 1999). Without good interaction between the writer and readers in argumentative writing, the main purpose cannot be achieved. The use of metadiscourse markers in an argumentative essay is closely linked to the norms surrounding persuasion

Citation: Papangkorn, P., \& Phoocharoensil, S. N. (2021). A Comparative Study of Stance and Engagement Used by English and Thai Speakers in English Argumentative Essays. International Journal of Instruction, 14(1), 867-888. https://doi.org/10.29333/iji.2021.14152a 
and argumentation. Apart from organizing the content clearly and following appropriate rhetorical structures to achieve the objective, a writer should be able to organize the content and make a strong argument in a rhetorical and interpersonal manner in accordance with the conventional practices of the community. Moreover, in order to construct an effective argument, writers must employ stance and engagement markers (Hyland, 2008). Therefore, it is important for Thai EFL learners to have knowledge of the use of metadiscourse to produce a written text that will interact with readers effectively. Furthermore, with the absence of the lexical bundles, the texts may not sound fluent; thus, the appropriate use of the lexical bundles is important for the writers towards a specific discipline. The present study focuses on stance and engagement in interactional metadiscourse based on the model of Hyland (2005). the current research study is intended to bridge this gap by examining the kinds, frequency, and use of Interactional metadiscourse of Thai EFL learners and native speakers of English in argumentative writing. Moreover, the study is aimed to provide an account of how patterns of stance markers, engagement markers, and participant-oriented bundles are conveyed in argumentative writing produced by native English speakers and non-native English speakers (Thai EFL learners), and also raise awareness among Thai EFL learners of using them in their academic prose.

\section{LITERATURE REVIEW}

\section{Argumentative Writing}

Argumentative writing, a major type of non-fiction writing, is defined as a composition that "attempts to support a controversial point or defend a position on which there is a difference of opinion" (Richards and Schmidt, 2002, p. 337). Hyland (1990) defines an argumentative essay by its purpose, which is persuading the reader of the validity of a central statement. According to Reid (1988), a writer takes a position on a controversial issue, provides reasons and opinions, clarifies, and illustrates those opinions to persuade the audience to agree or disagree with an issue in argumentative writing. Research studies have focused on various aspects of argumentative writing; for example, $\mathrm{Hu} \& \mathrm{Li}$ (2015) looked at discourse connectives, whereas Zhang (2015), Wang and Zhang (2006), and Pang (2009) focused on demonstratives, chunks, and lexical bundles, respectively. Some studies have compared the argumentative writing of native and nonnative English speakers with different focuses, such as discourse connectors (Prommas and Sinwongsuwat, 2014) and quantifiers (Wijitsopon, 2017).

Metadiscourse is "quite relevant" in argumentative writing because "authors refer quite frequently to the state of the argument, to the reader's understanding of it, or to the author's understanding of his own argument" (Crismore, 1989, p. 93). Thus, numerous studies (e.g. Gholami, Nejad and Pour, 2014) have been undertaken based on the assumption that argumentative writing contains a generous amount of the markers.

\section{Metadiscourse}

Metadiscourse is a fuzzy term (Hyland, 1998), leading researchers to define it in different ways and call it by various names such as evaluation (Hunston and Thompson, 2000), attitude (Halliday, 1994), epistemic modality (Hyland, 1998), appraisal (Martin, 
2000), stance (Biber and Finegan, 1989; Hyland, 1999) and metadiscourse (Crismore, 1989; Hyland and Tse, 2004; Hyland, 2005). Harris (1959) coined the term metadiscourse to propose a method of understanding language in use, showing the attempts of writers or speakers to engender a specific perception of a text in their receivers (Hyland, 2005), and to better express the pragmatic relationship between writer and reader (Beauvais, 1989).

Hyland (2005, p.37-38) defines metadiscourse as a "cover term for the self-reflective expressions used to negotiate interactional meanings in a text, assisting the writer (speaker) to express a viewpoint and engage with readers as members of a particular community." He categorized metadiscourse as interactive and interactional. This taxonomy is derived from Thompson and Thetela's (1995) concept. Hyland (2005, p.49) defines interactive metadiscourse as "the writer's awareness of a participating audience and the ways he or she seeks to accommodate its probable knowledge, interests, rhetorical expectations, and processing abilities," whereas the interactional metadiscourse is defined as "the ways writers conduct interaction by intruding and commenting on their message." For the latter, there are five types as shown in Table 1; meanwhile, engagement markers are divided into five categories as shown in Table 2.

Table 1

Hyland's metadiscourse model (2005, p.49)

\begin{tabular}{lll}
\hline Interactional & Involve the reader in the text & Resources \\
\hline Hedges & withhold commitment and open dialogue & might; perhaps; possible; about \\
\hline Boosters & emphasize certainty or close dialogue & in fact; definitely; it is clear that \\
\hline Attitude markers & express writer's attitude to proposition & unfortunately; I agree; surprisingly \\
\cline { 2 - 3 } Self-mentions & explicit reference to author & I; me; my; our \\
\cline { 2 - 3 } Engagement markers & explicitly build relationship with reader & consider; note; you can see that \\
\hline
\end{tabular}

Table 2

Five elements of engagement in academic writing (Hyland, 2005)

\begin{tabular}{lll}
\hline Elements & Definition & Examples \\
\hline Reader pronouns & $\begin{array}{l}\text { Explicitly refer to the readers and bring them } \\
\text { into the discourse }\end{array}$ & you/your/we \\
\hline Directives & Instruct the readers to perform certain actions & $\begin{array}{l}\text { Consider (imperative)/you should } \\
\text { administer/it is important to note that }\end{array}$ \\
\hline $\begin{array}{l}\text { Questions } \\
\text { knowledge }\end{array}$ & $\begin{array}{l}\text { Explicitly ask something of the readers } \\
\text { invoke 'sharedness' of certain knowledge }\end{array}$ & It is well known/obviously/of course \\
\hline Personal asides & $\begin{array}{l}\text { Briefly break off the discourse to offer a } \\
\text { comment }\end{array}$ & By the way/incidentally/- \\
\hline
\end{tabular}

Note. ${ }^{1}$ Use of dash to add comments.

\section{Stance}

Hyland (2005) defined stance as "an attitudinal dimension that includes features which refer to the ways writers present themselves and convey their judgments, opinions, and commitments" (p. 176). Hyland (2005) categorized stance into four main elements, which are hedges, boosters, attitude markers, and self-mentions. First, hedges are words such as might, perhaps, could, would, and possible. These words are used to highlight that a statement is shown based on a writer's interpretation rather than a fact. Also, they 
can be used to serve as an indication of tentativeness in communication and minimize the degree of confidence and precision, which the writers prefer to convey. Second, boosters, boosting, or emphatics are devices like obviously, demonstrate, actually, clearly and surely, which are used to highlight or deemphasize certainty because they allow authors to avoid conflicting views and also stress shared information and group membership. Third, attitude markers are the words such as agree, prefer, important, dramatic and amazing. By conveying agreement and signaling shared values, attitude markers play an important role in showing writers' attitude toward the subject matter. Attitudes to propositions can be clearly expressed by applying attitude verbs such as disagree, agree, and prefer, attitude adverbs such as hopefully, unfortunately, and unbelievably), adjectives such as amazing, appropriate, logical, remarkable, and shocked) and punctuation (!). Finally, self-mention is used to indicate the degree of overt author presence in the text, particularly, by using the first person subject and object pronouns such as $I$, we, me, us) and by using possessive adjectives such as our to show a particular authorial identity. In short, the self-mention refers to writers' explicitly by showing themselves and projecting their particular identity in academic discourse to construct authorial identity.

\section{Engagement}

According to Hyland's (2005) study, engagement means "A dimension where writers acknowledge and connect to others, recognizing the presence of their readers, pulling them along with their arguments, and including them as discourse participants (p. 176)." The engagement generally copes with how writers recognize their reader's presence by leading them to the text explicitly. According to Hyland's (2005) framework, the engagement concept can be separated from the parallel stance concept that means "the ways writers present themselves and convey their judgments, opinions, and commitments (p. 176)." The concept of stance and engagement are the two important elements for creating a convincing and successful academic text when an academic writing is considered as a dialogue between the writer and the reader, including both as discourse participants. According to Hyland's (2005), the engagement consists of five elements, which are reader pronouns, directives, questions, appeals to shared knowledge, and personal asides as in Table 2. Firstly, reader pronouns are explicit references to the readers by using personal pronouns. Acknowledge the reader's presence explicitly by addressing them within the discourse is its function. Secondly, directives are expressions that are used as an obligation directed toward the readers. The form of imperatives, modals of obligation, or co-occur with adjectives of necessity, such as important or necessary can be used in this element. Thirdly, questions are explicit interrogatives, which are directed toward the readers. Fourthly, appeals to shared knowledge are used to highlight the sharedness of each academic community by overtly referring to it. Finally, personal asides are used to shortly break off the ongoing discourse mostly by using a hyphen to give more information about what has just been said. Using these expressions may get the feeling like talking more directly to the readers, and the intimacy between the reader and the writer might be increased. 


\section{Lexical Bundles}

Lexical bundles have been the focus of a number of corpus studies in the field of EAP and ESP because combinations of words vary depending on the community; as a result, numerous studies have been conducted to examine field-specific meanings that perform a variety of rhetorical functions. Biber coined the term lexical bundles to refer to "recurrent expressions, regardless of their structural status" (Biber and Conrad, 1999, p.990). Researchers define this concept using different terms. Biber, Conrad, and Cortes (2004) define them as multi-word sequences, while Hyland (2012, p.150) defines them statistically as the most frequently recurring sequences of words in any collection of texts. Researchers differ on how frequently word combinations must occur before they are termed lexical bundles. For Biber et al. (1999), a word must occur ten times per million words of four-word expressions and appear in more than five texts, whereas forty occurrences in a one-million word corpus is called a lexical bundle (Biber et al.,2004). Altenberg (1998, p.101) defined "recurrent word-combinations as any continuous string of words occurring more than once in identical form." Therefore, every recurrent word-combination that occurs more than one time is considered a lexical bundle in the present study.

Researchers have categorized the structure of lexical bundles differently. However, many studies (e.g. Allen, 2009; Biber et al., 2004; Byrd and Coxhead, 2010; Chen and Baker, 2010; Cortes, 2001; Hyland, 2008a and 2008b) have adopted the classification system for the structure of lexical bundles from Biber et al. (1999). For the participantoriented bundles, the structural classification of Biber et al. (1999) was used as the framework, as this is one of the most practical taxonomies for lexical bundle analysis. This structural classification also contains numerous finer structural types, which can describe most of the grammatical patterns found in the corpora. Biber et al. (1999) divide the lexical bundles into two categories: conversational and academic. In the present study, both categories were used, but new categories were added to encompass all of the findings of the structural types of 3-word and 4-word participant-oriented bundles as shown in previous studies (e.g. Cortes, 2013; Wongwiwat, 2016). Apart from the analysis of structural types, which rely on grammatical features, the categorization of discourse functions is also important. These functions focus on the assessment of semantic and pragmatic features, and the bundles are grouped according to meaning and purpose. A taxonomy of functional categories was originally generated by Cortes (2001). Later, Biber et al. (2004) developed Cortes's (2002) categories, and various studies focusing on lexical bundles used this revised taxonomy as a model to investigate the bundles (e.g. Ädel and Erman, 2012; Chen and Baker, 2010; Cortes, 2001 and 2006. Hyland (2008b) offers an alternative set of functions, which are aimed at differentiating between spoken and written modes of discourse. The functions introduced by Hyland (2008b) were used as the model for the present study because argumentative texts are considered to be academic prose. Thus, Hyland's (2008b) taxonomy is most suitable for use in the analysis of the functions of participant-oriented bundles. The functions with definitions from Hyland (2008b, p.13-14) are shown in Table 3 below: 
Table 3

Hyland's taxonomy of lexical bundles

\begin{tabular}{|c|c|}
\hline Type of function & Description \\
\hline Research-oriented & Help writers structure their activities and real-world experiences \\
\hline Location & Indicate time/place (at the beginning of, at the same time) \\
\hline Procedure & Provide rationale or function (the role of the, the purpose of the) \\
\hline Quantification & Related to measurement ( $a$ wide range of, one of the most) \\
\hline Description & Related to depiction of features (the size of the, the structure of the) \\
\hline Topic & Related to the field of research (of lexical bundles in) \\
\hline Text-oriented & Concern the organization and meaning of the text \\
\hline Transition signals & $\begin{array}{l}\text { Establish additive or contrastive links between elements(in addition to the, } \\
\text { in contrast to the, on the other hand) }\end{array}$ \\
\hline Resultative signals & $\begin{array}{l}\text { Indicate inferential or causative relationships between elements (as a result } \\
\text { of, it was found that, these results suggest that) }\end{array}$ \\
\hline Structuring signals & $\begin{array}{l}\text { Text-reflexive markers which organize stretches of discourse or direct the } \\
\text { reader elsewhere in the text (in the next section) }\end{array}$ \\
\hline Framing signals & $\begin{array}{l}\text { Situate arguments by specifying limiting conditions (in the case of, on the } \\
\text { basis of, with respect to the) }\end{array}$ \\
\hline Participant-oriented & Focus on the writer or reader of the text \\
\hline Stance features & Convey the writer's attitudes and evaluations (it is possible that) \\
\hline Engagement features & Address readers directly (it should be noted, as can be seen) \\
\hline
\end{tabular}

\section{Research Questions}

1. What are the similarities and differences between Thai EFL university students' and native English speakers' argumentative writing with regard to stance and engagement?

2. What are the similarities and differences of the structural patterns between Thai EFL university students' and native English speakers' argumentative writing with regard to 3 word and 4-word lexical bundles?

\section{METHOD}

\section{The Sample}

This study employed two corpora, namely LOCNESS and Thai students' argumentative corpus; the latter corpus is referred to as a learner corpus because the texts in the corpus were produced by learners. The details are given below.

Louvain Corpus of Native English Essays (LOCNESS)

Louvain Corpus of Native English Essays (LOCNESS), henceforth NATIVE, used in this study as the native speaker reference corpus, was compiled by the ICLE team at Louvain-la-Neuve. The texts in the LOCNESS corpus were gathered by the Centre for English Corpus Linguistics at the Catholic University of Louvain, Belgium in 1998, and it was then made available for public use. In the present study, American and British university students' essays were employed because the ages of the participants were similar to those in the THAI corpus, and all of the essays are argumentative essays. Thus, LOCNESS in the present study includes 321 texts, consisting of 229,607words.

\section{Thai Learner Corpus}

Students majoring in English and others who were studying in English IV, which is an English foundation course at an international university in Thailand, were the 
participants who contributed the data for the corpus, with their ages ranging from 19 to 22. Most of them were third-year students. For English IV, the students are expected to possess analytical skill and to have mastered basic writing skills before taking this course. Their English proficiency varies from the intermediate to advanced levels. The corpus was compiled by collecting student papers from the university. The instructors who taught the English IV courses invited students to participate. The corpus includes written production of argumentative essays. The essays are compositions they were asked to write as a part of the final exam without help from teachers or the use of reference tools such as dictionaries or textbooks. The reason why final exam essays were used is that they are the final products from the students after they had been trained in the methods of writing well-organized argumentative essays for five weeks, which was assumed to have improved the quality of their writing, allowing for a comparison of their use of metadiscourse markers with that of native-speaking learners. The essay topics in the THAI and NATIVE corpora were mostly dissimilar. For the NATIVE corpus, the topics included boxing, single-sex schools, privacy issues, foxhunting, violence on television, capital punishment and politics; in contrast, for the THAI corpus, some of the topics were soft drinks, mandatory retirement, CCTV, gambling, entertainment businesses, smoking, cannabis, marriage, street food and living in a dormitory. However, there were some topics that both corpora had in common, namely abortion, gun control, drinking alcohol, euthanasia, the death penalty, animal testing, technology, same-sex marriage and technology. Paquot and Granger (2012) and Wijitsopon (2017) contend that one of the important factors that should be taken into consideration when using learner corpora is the differences in the topics of the essays; therefore, this factor was taken into account when the results of the present study were interpreted. Moreover, with regard to the essay length, the average length was about 390 words in the THAI corpus, whereas the average length was about 500 words for the NATIVE corpus, a factor that was also taken into account. For the corpus size, LOCNESS includes 321 texts, consisting of 229,607words, whereas the THAI corpus was made up of 613 texts, consisting of 229,606words after removing all non-textual scripts and irrelevant information.

\section{Design of the study}

A mixed-method design was adopted to answer the research questions. The quantitative method is vital in terms of creating a brief view of the findings, while the qualitative method gives a robust and comprehensive picture that compensates for the deficiencies of purely numerical analyses. In this study, both quantitative and qualitative analysis of the frequency of the stance, engagement, stance bundles and engagement bundles in argumentative texts were used to answer the research questions. Moreover, both topdown and bottom-up approaches (as shown in Table 5 below) were used when coding the metadiscourse resources. In the top-down approach, the researcher began the coding with an interpretation of the attitudinal meaning from higher order semantic functions before working down to lexis; in other words, it started with the categories the researcher wished to examine from the list of potential metadiscourse items from Hyland (2005). Thus, a predefined list was generated, which could be used for an in-depth investigation later on. Conversely, the bottom-up approach was used to focus on the 
lexical expression of attitude. The researcher identified attitudinal patterns during the process, starting by classifying every possible lexical bundle of the corpora with regard to the 3-word and 4-word participant-oriented bundles.

\section{Tool}

The most recently updated version of the concordance software AntConc 3.4.3 (Anthony, 2014) from http://www.laurenceanthony.net was used in the analysis. It is a freeware with various purposes and platform tools that are used for analyzing markers or even lexical bundles. A potential concordancer, cluster and lexical bundle analysis tool, word and keyword frequency generator, and a word distribution plot are also provided in this software. AntConc is a set of programs which investigates how words work in texts. The existence of every single word form can be counted before listing them in ascending or descending order of alphabetically or frequency in this program. Statistics of total amount of words, word lengths, and quantity of sentences are also presented. Creating concordances or lists of words in context, finding collocation, identifying common expressions, and displaying a graphical map displaying where the word arises in the corpus can be done with this program. By keying a word into the program, it will identify all the amounts of word in the texts and display the situation according to user's favourite. The words or sets of words can be distributed by Keywords tool through a variety of parts of the text. Every key word arises in the texts will be displayed in a graphical map.

\section{Data Analysis}

To answer the two research questions, the data analysis was based on the framework of Hyland (2005) as shown in Table 4 below.

Table 4

Key Resources of Academic Interaction (Hyland, 2005)

\begin{tabular}{ll}
\hline Interaction & Engagement \\
Stance & 1. Reader pronouns \\
\hline 1. Hedges & 2. Directives \\
2. Boosters & 3. Questions \\
3. Attitude markers & 4. Shared knowledge \\
4. Self-mention & 5. Personal asides \\
\hline
\end{tabular}

\section{Table 5}

Data Analysis Procedure

\begin{tabular}{ll}
\hline Interactional Metadiscourse Markers & Metadiscourse bundles/Participant-oriented bundles \\
\hline 1. Identifying markers according to Hyland's (2005) & 1. Identifying participant-oriented bundles using \\
list by using top-down / corpus-based approach & bottom-up / corpus-driven approach \\
$\begin{array}{ll}\text { 2. Doing quantitative analyses using log-likelihood } & \text { 2. Doing quantitative analyses using log-likelihood } \\
\text { (LL) } & \text { (LL) } \\
\text { 3. Doing qualitative analyses to examine how } & \text { 3. Doing qualitative analyses to examine how } \\
\text { markers were used. } & \text { participant-oriented bundles were used. }\end{array}$ \\
\hline
\end{tabular}

The data analysis procedure for examining the stance and engagement were separated into three main phases. First, instances of stance and engagement were retrieved from the NATIVE and THAI corpora. Next, all the listed instances were investigated 
carefully at the sentential level, or even at the paragraph level if it is necessary. Then the results from the corpus software were double-checked by the researchers with the purpose of ensuring that the instances drawn definitely functioned as intended markers within the prescribed context. Second, after completing the first phase, the second phase of the analysis followed. Qualitative analysis of the markers was used in this phase. During this stage, the linguistic environment of the key item which the researchers could get from each concordance line was investigated. With the purpose of investigating the interesting instances in depth, the concordance lines of at least one sentence level or even one paragraph level was placed into the analysis when it was needed, more than one sentence before and/or after the instances of the markers were referred so as to make a decision of the usage patterns of the writers. All of the concordance lines were investigated to categorize each occurrence of the markers with the intention to answer the first research question. However, not all occurrences of the target words were used because some occurrences of some features were not be able to group as stance or engagement. Therefore, these are the reasons why some occurrences were omitted from the analysis. Third, after the markers had been investigated and their functions were been determined, the frequencies from each corpus were used to compare in order to see the similarities and differences; then, they were used to answer the first research question. After that log-likelihood calculation were applied by using log-likelihood calculation with the purpose of establishing the statistical significance of differences between the results of the two corpora along each dimension. Normalizing frequency was also conducted in order to see a frequency represented as a percentage of the whole in comparison to any other quantity. Only the raw frequency alone is unable to compare because the number of words between the corpora are not exactly the same.

The data analysis procedure for examining the participant-oriented bundles were separated into four main phases. First, the focus is on the frequency. In identifying 3word and 4-word participant-oriented bundles, there are two main aspects of frequency that are needed to be considered. The first aspect is the frequency of occurrence and the second one is the range of texts that the bundles are discovered. Because of the size of the two corpora used in the present study, the cut-off point for the participant-oriented bundles in the present study was set differently as follows. First, set 3 for the 3 -word stance bundles because it is more common compared to 4-word stance bundles. Second, set 2 for 4-word stance bundles (Altenberg, 1998) since the size of the corpus was not very big and it is the target bundles of the present study. Third, set 2 for 3-word and 4 word engagement bundles because these bundles were rarely found in the previous studies, according to Altenberg (1998, p.101) stated that in defining "recurrent wordcombinations as - any continuous string of words occurring more than once in identical form" and it is also the target bundles of the present study. In addition, both 3-word and 4-word participant-oriented bundles occurred at least two texts were considered as the bundles of the present study. After these two main aspects were set, AntConc was used in order to extract the bundles from the two corpora. After that, with the aim of making sure that there is no error for the results and there is no an overlapping of the data, the researchers manually checked the results again and the raw data set were edited. Second, after getting the bundles from the frequency analysis, then, the functional analysis will 
be conducted. The present study is different from a number of studies during this stage because the present study will focus on the participant-oriented bundles regarding to stance and engagement only; therefore the research-oriented and text-oriented bundles will not be considered. Thus, it is necessary for the present study to analyze the functions first and then the structure of the 3-word and 4-word participant-oriented bundles. At this stage, each bundle in context will be looked at and put them into the categories of their functions within the text. Therefore, the lexical bundles, which appear from the frequency analysis, but the functions of them are not used as the participantoriented bundles. These lexical bundles will be ignored, and will not be used to analyze for the structural analysis in the next stage. Third, after getting the bundles from the frequency analysis and the functional analysis, then the structural type will be concerned by conducting a structural analysis according to the structural type of Biber et al's (1999, p.996) classification of the structural type of lexical bundles; moreover, new categories were added to Biber et al.'s (1999, p.996) classification of the structural type in order to fit with the findings of the structural type of 3-word and 4-word participant-oriented Bundles. Finally, after getting the results from each phase which was frequency, functional, and structural analysis, the 3-word and 4-word participantoriented bundles used by NATIVE and THAI extracted from each corpus type were compared in order to answer the second research question.

\section{FINDINGS AND DISCUSSION}

\section{Similarities and Differences between the Two Corpora regarding Stance and Engagement}

The analysis was conducted on the two corpora. The overall frequency of interactional metadiscourse markers in terms of items and percentage is presented in Table 6 below.

Table 6

Frequency of overall interactional metadiscourse resources

\begin{tabular}{|c|c|c|c|c|c|}
\hline & & Items per & & Items per & \\
\hline & THAI & 10,000 words & NATIVE & 10,000 words & LL Ratio $(* \mathrm{p}<0.05)$ \\
\hline Stance & 11355 & 494.54 & 10832 & 471.76 & (+) 12.33 \\
\hline Engagement & 5394 & 234.92 & 3641 & 158.58 & (+) 342.30 \\
\hline Total & 16749 & 729.47 & 14473 & 630.34 & (+) 166.07 \\
\hline
\end{tabular}

The results showed some differences with regard to the use of stance and engagement resources between NATIVE and THAI. First, regarding the overall frequencies of stance markers, Table 6 indicated that THAI used stance resources more frequently at 11,355 when compared to NATIVE at 10,832 in their argumentative texts. Second, regarding engagement markers, THAI also employed the resources more frequently at 5,394 when compared to NATIVE at 3,641. As the LL was above 3.84, the difference between the two corpora was deemed to be significant at the $p<0.05$ level, this meant that stance and engagement resources were used more frequently by Thai learners compared to native speakers.

The results of the analysis of the frequency of stance markers in the four sub-categories in the two corpora are presented in Table 7. 
Table 7

Frequency of stance resources in sub-categories

\begin{tabular}{llllll}
\hline \multirow{2}{*}{ Stance Resources } & THAI & $\begin{array}{l}\text { Items per } \\
10,000 \text { words }\end{array}$ & NATIVE & $\begin{array}{l}\text { Items per } \\
10,000 \text { words }\end{array}$ & LL Ratio $(* \mathrm{p}<0.05)$ \\
\hline Hedges & 4761 & 207.36 & 5006 & 218.02 & $(-) 6.15$ \\
\hline Boosters & 2423 & 105.53 & 2344 & 102.09 & $(+) 1.31$ \\
\hline Attitude Markers & 1337 & 58.23 & 714 & 31.10 & $(+) 192.26$ \\
\hline Self-mentions & 2834 & 123.43 & 2768 & 120.55 & $(+) 0.78$ \\
\hline Total & 11355 & 494.54 & 10832 & 471.76 & $(+) 12.33$ \\
\hline
\end{tabular}

Turning to the four sub-categories of stance markers, the differences in the frequencies of hedges and attitude markers were significant, but this was not the case for boosters and self-mentions.

The results revealed several notable findings. First, as for hedges, which accounted for the biggest proportion of all the stance markers in both corpora at 218.02 items per 10,000 words for NATIVE and 207.36 for THAI corpus, NATIVE obviously employed more hedge devices than THAI did, which was in line with the results from the previous studies, (e.g. Sukhanindr, 2008; Petchkij, 2019) which showed that native writers used higher hedges than Thai writers. However, the findings contrasted with the findings from Incharoensak (2018), where native writers used fewer hedges than Thai writers. To conclude, the hedges were used less frequently by Thai learners and the results were significant difference. This finding indicated that both THAI and NATIVE in the present study favored tentative expression and did not show much confidence in their argumentative texts. Getkham (2016) stated that culturally inherent, which are product of face-saving and polite manners might be the reason for the dominant use of hedges. Thai learners' L1 conventions might have been the reason that they used less hedging than native speakers since there are different hedging strategies in Thai language, most of which are employed in conversations (Prasithrathsint, 2015). The use of final particles is considered to be the most frequent hedging strategy; the difficulty of transferring this into English writing likely leads to a lack of hedging in English written by Thais. Moreover, being authoritative is more common in English-speaking culture, which results in greater use of direct statements or propositions (Prasithrathsint, 2015).

Self-mention was the second most frequently used stance resource in both corpora, which meant that both NATIVE and THAI contained examples of explicating authorial identity. The results showed that markers were more frequently used in THAI than NATIVE, indicating that Thai writers try to maintain the active voice in a text. Although overuse of stance markers was seen in THAI, no great differences were observed in the use of self-mention between the two corpora. The results, however, are not in line with Hayisama et al. (2019), who found that self-mention was used the least by Thais in the discussion part, although this might be because of genre differences. This implies that Thai writers rarely present their identity in their arguments and also do not realize that self-presenting in arguments is a trend (Hayisama et al., 2019),with numerous studies (e.g. Hyland, 2004; Mur-Duenas 2011) having revealed that self-mention is a common tool used by academic writers to enhance credibility(Hyland, 2004; Mur-Duenas, 2011). 
Meanwhile, Thai writers seem to try to maintain some distance from the readers, likely believing that this is better suited to academic discourse (Hayisama et al., 2019).

Boosters were the third most frequently used marker in both NATIVE and THAI, and they were employed considerably more frequently in THAI than NATIVE. The results are consistent with the results of Hayisama et al. (2019), which showed that Thai learners used fewer boosters than hedges, and preferred to hedge their statements rather than use assertive markers such as boosters to convince readers. This result does not accord with Hinkel (2002), who determined that ESL students, especially Asian students, had a preference for using boosters to strengthen their claims and to place emphasis on the truth of a statement. However, Hayisama et al. (2019) claim that the differences between the results of Hinkel (2002) and their study may be due to the students' language proficiency, not cultural factors.

Finally, attitude markers accounted for the smallest proportion in both NATIVE and THAI, but THAI learners used the markers more. Similarly, attitude markers were the least used by the speakers in the corpus of students' classroom speeches in Siribud (2016), as well as Lee and Subtirelu (2015). Lee and Subtirelu (2015) argue that using attitude markers is not necessary in spoken discourse since there are signals from other paralinguistic features, which are used to show attitudes toward the subject; thus, compared to written discourse, verbal expressions of attitudes are much more necessary since these paralinguistic features are missing. The results from Suntara and Chokthawikit (2018) support the work of Lee and Subtirelu (2015). Markers were employed most frequently in Background/Objectives/Moves at $80 \%$ in research article abstracts from Public Health Journals, with writers inserting their attitudes to present their direct empirical propositions in these moves.

The overall engagement devices in the five sub-categories between NATIVE and THAI are displayed in Table 8.

Table 8

Overall distribution of engagement devices in sub-categories

\begin{tabular}{llllll}
\hline & THAI & $\begin{array}{l}\text { Items per } \\
10,000 \text { words }\end{array}$ & NATIVE & $\begin{array}{l}\text { Items per } \\
10,000 \text { words }\end{array}$ & $\begin{array}{l}\text { LL Ratio } \\
(* \mathrm{p}<0.05)\end{array}$ \\
\hline Reader References & 2918 & 127.09 & 1998 & 87.02 & $(+) 173.20$ \\
\hline Directives & 2443 & 106.40 & 1291 & 56.23 & $(+) 361.28$ \\
\hline Questions & 0 & 0.00 & 171 & 7.45 & $(-) 237.06$ \\
\hline Appeals to Shared Knowledge & 31 & 1.35 & 125 & 5.44 & $(-) 60.69$ \\
\hline Personal Asides & 2 & 0.09 & 56 & 2.44 & $(-) 63.01$ \\
\hline Total & 5394 & 234.92 & 3641 & 158.58 & $(+) 342.30$ \\
\hline
\end{tabular}

As can be seen, the frequencies of all five sub-categories between the two corpora were significantly different. Directives were used more frequently in THAI corpus, which is in line with Rasti's (2011) study, which found that in non-native student argumentative essays showed greater use than in native student argumentative essays. Moreover, with regard to questions, native speakers employed more, which is in line with the Rasti's (2011) study, where questions were used more in native student argumentative essays when compared to the non-native ones. 
The most frequently employed device in NATIVE was reader reference, followed by directives, whereas questions, appeals to shared knowledge and personal asides were relatively used less. This is consistent with the previous findings. Similar to the THAI corpus, there were a total of 2,918 reader references and 2,443 directives, while shared knowledge appeals and personal asides were used much less often. It is worth noting that questions as a strategy to engage the readers were not found in THAI.

In Hayisama et al. (2019), Thai writers employed engagement markers at $12.48 \%$, indicating that it is not a regular practice. This is in agreement with Mur-Duenas (2011), who discovered that engagement markers were employed the least when compared to other types of interactional metadiscourse markers. However, this was dissimilar to the results in Chan and Tan's (2010) study, which found that engagement markers were the most frequently employed device among the students. Two reasons for the less frequent use were poor exposure to lexical terms for engagement markers and a sociocultural practice from the L1 background of the students (Hayisama et al., 2019).Moreover, in Eastern culture, it is uncommon to persuade the interlocutor in an explicit manner (Hayisama et al., 2019), and Asian writers tend to avoid completely presenting themselves in discourse because of face-saving concerns, as this may require them to take full responsibility when there is miscommunication (Asma and Pederson, 2009).

The ranking of engagement resources used by Asian university students in Kitjaroonchai (2019) was in line with the ranking in THAI in the present study. Kitjaroonchai (2019) discovered that reader reference was used the most at $50.7 \%$ by the students, followed by directives at $32.9 \%$ and appeals to shared knowledge at $11.4 \%$. The engagement markers used least were personal asides at $3.6 \%$ and questions at $1.4 \%$. Moreover, in Lee and Deakin's (2016) study, directives were the second most used marker, in line with the results of the present study but not in agreement with the results of Hyland (2002, 2005). Looking at directives in detail, Thai learners seldom used imperatives, considered the "most imposing" and "risky" type of directive (Hyland, 2002), instead preferring modal verbs such as should at $63.43 \%$; because imperatives - commonly found in the hard sciences - explicitly direct readers to perform some action, Thai students rarely employ them (Hyland, 2002). Questions and personal asides were also rarely used in the present study, which is in line with the results from Kitjaroonchai's (2019) study suggesting that students were not well-trained enough in the use of the devices to employ them in argumentative essays.

Similarities and Differences of the Structural Patterns between the Two Corpora regarding 3-word and 4-word Lexical Bundles

The overall descriptive results of the stance and engagement bundles used in the argumentative texts are displayed in Table 9 - 12 below.

Table 9

Total number of types of stance bundles

\begin{tabular}{llllll}
\hline $\begin{array}{l}\text { Total number of types of Stance } \\
\text { Bundles }\end{array}$ & THAI & $\begin{array}{l}\text { Items per } \\
10,000 \text { words }\end{array}$ & NATIVE & $\begin{array}{l}\text { Items per } \\
10,000 \text { words }\end{array}$ & $\begin{array}{l}\text { LL Ratio } \\
(* \mathrm{p}<0.05)\end{array}$ \\
\hline Total number of 3-word Stance Bundles & 91 & 3.96 & 147 & 6.40 & $(-) 13.30$ \\
\hline Total number of 4-word Stance Bundles & 77 & 3.35 & 130 & 5.66 & $(-) 13.72$ \\
\hline Total number of Stance Bundles & 168 & 7.32 & 277 & 12.06 & $(-) 26.97$ \\
\hline
\end{tabular}


Table 10

Total number of types of engagement bundles

\begin{tabular}{llllll}
\hline Total number of types of Engagement Bundles & THAI & $\begin{array}{l}\text { Items per } \\
10,000 \text { words }\end{array}$ & NATIVE & $\begin{array}{l}\text { Items per } \\
10,000 \text { words }\end{array}$ & $\begin{array}{l}\text { LL Ratio } \\
(* p<0.05)\end{array}$ \\
\hline Total number of 3-word Engagement Bundles & 2 & 0.09 & 2 & 0.09 & $(+) 0.00$ \\
\hline Total number of 4-word Engagement Bundles & 1 & 0.04 & 8 & 0.35 & $(-) 6.20$ \\
\hline Total number of Engagement Bundles & 3 & 0.13 & 10 & 0.44 & $(-) 3.98$ \\
\hline
\end{tabular}

Table 11

Overall frequencies and percentages of stance bundles

\begin{tabular}{llllll}
\hline $\begin{array}{l}\text { Frequencies and Percentages of Stance } \\
\text { Bundles }\end{array}$ & THAI & $\begin{array}{l}\text { Items per } \\
10,000 \text { words }\end{array}$ & NATIVE & $\begin{array}{l}\text { Items per } \\
10,000 \text { words }\end{array}$ & $\begin{array}{l}\text { LL Ratio } \\
(* \mathrm{p}<0.05)\end{array}$ \\
\hline Total number of 3-word Stance Bundles & 1932 & 84.14 & 1534 & 66.81 & $(+) 45.80$ \\
\hline Total number of 4-word Stance Bundles & 923 & 40.20 & 525 & 22.87 & $(+) 110.82$ \\
\hline Total number of Stance Bundles & 2855 & 124.34 & 2059 & 89.67 & $(+) 129.51$ \\
\hline
\end{tabular}

Table 12

Overall frequencies and percentages of engagement bundles

\begin{tabular}{llllll}
\hline $\begin{array}{l}\text { Frequencies and Percentages of Engagement } \\
\text { Bundles }\end{array}$ & THAI & $\begin{array}{l}\text { Items per } \\
10,000 \text { words }\end{array}$ & NATIVE & $\begin{array}{l}\text { Items per } \\
10,000 \text { words }\end{array}$ & $\begin{array}{l}\text { LL Ratio } \\
\left({ }^{*} \text { p }<0.05\right)\end{array}$ \\
\hline Total number of 3-word Engagement Bundles & 80 & 3.48 & 49 & 2.13 & $(+) 7.52$ \\
\hline Total number of 4-word Engagement Bundles & 2 & 0.09 & 34 & 1.48 & $(-) 34.46$ \\
\hline Total number of Engagement Bundles & 82 & 3.57 & 83 & 3.61 & $(-) 0.01$ \\
\hline
\end{tabular}

As seen in Table 11 above, the total number of the words analyzed was 229,607 for the NATIVE corpus and 229,606 for the THAI corpus: only 89.67 per 10,000 words were stance bundles in NATIVE, whereas 124.34 per 10,000 words were stance bundles in THAI. As the results show, NATIVE had fewer stance bundles than THAI, similar to the findings of Muslu's (2018) study in which the native speakers used lexical bundles the least among three groups: Japanese, Turkish and native speakers of English.

The results are also consistent with Wei and Lei (2011) and Jalali et al. (2008) in that non-native speakers showed greater use of lexical bundles than native speakers. In addition, the number of stance bundles found in the present study is higher than the amount found in previous studies. For instance, Hyland (2008a) found 629 bundles in a corpus of nearly 3.5 million, and Wei and Lei (2011) found 241 bundles in a 2.5 million corpus, although this might be due to the type of genre. LL ratio measurement showed significant differences between the two corpora in terms of 3-word, 4-word, and overall stance bundle frequency.

For engagement bundles, the LL value revealed 3-word engagement bundles were used more by Thai learners, but 4-word engagement bundles and overall engagement bundles were found more in the NATIVE corpus. There were significant differences in terms of the frequency of 3-word and 4-word engagement bundles. Moreover, the LL ratio showed Thai learners should focus on 4-word engagement bundles.

A comparison of the $\mathrm{T} / \mathrm{t}$ ratio of 4 -word stance bundles revealed that the $\mathrm{T} / \mathrm{t}$ ratio of the bundles used in NATIVE was higher than THAI, meaning that there was more varied use of 4-word stance bundles in NATIVE. The T/t ratio of the overall stance bundles used in NATIVE at $13 \%$ was higher than THAI at 5\%. This means that NATIVE contained more varied stance bundles, as 13 of every 100 words were a stance bundle, whereas only five of every 100 words in THAI were stance bundles. For instance, 'in my 
opinion' was used 309 times in THAI, whereas it was used 28 times in NATIVE. Therefore, although the overall number of stance bundles in NATIVE was lower than in THAI, there was lesser variety in the use of the bundles in the latter.

Similar to the stance bundles, the results showed that although NATIVE had less engagement bundles, a greater variety was evident; conversely, THAI contained more engagement bundles, but they were not as varied. Although NATIVE contained a greater variety of 3-word engagement bundles, the use of 4-word engagement bundles was less varied than in THAI due to the lower frequency of the use of 4-word engagement bundles. Finally, for the overall engagement bundles, NATIVE had a greater variety.

This finding is similar to the results of Muslu's (2018) study, which showed that native speakers used fewer but more varied bundles; on the other hand, EFL learners used more bundles, but with lesser variety, with similar, or the same, bundles used in many instances. The results are consistent with Allen (2009), Adel \& Erman (2012), and Chen (2012), who determined that non-native speakers used more limited and less varied lexical bundles.

Structural characteristics of target bundles are shown in Table 13-14 below.

Table 13

Summary of the structural features of the 3-word stance bundles

\begin{tabular}{|c|c|c|c|c|c|}
\hline 3-word Stance Bundles & THAI & $\begin{array}{l}\text { Items per } \\
10,000 \text { words }\end{array}$ & NATIVE & $\begin{array}{l}\text { Items per } \\
10,000 \text { words }\end{array}$ & $\begin{array}{l}\text { LL Ratio } \\
(* \mathrm{p}<0.05)\end{array}$ \\
\hline $\begin{array}{l}\text { 1. Noun phrase with of-phrase fragment e.g. the results } \\
\text { of }\end{array}$ & 1 & 0.04 & 28 & 1.22 & $(-) 31.50$ \\
\hline $\begin{array}{l}\text { 2. Noun phrase with other post-modifier fragment e.g. } \\
\text { the hope that }\end{array}$ & 13 & 0.57 & 133 & 5.79 & $(-) 114.71$ \\
\hline $\begin{array}{l}\text { 3. Other prepositional phrase fragments e.g. in my } \\
\text { opinion }\end{array}$ & 309 & 13.46 & 37 & 1.61 & (+) 244.34 \\
\hline 4. Anticipatory it + verb/adj e.g. it is common & 388 & 16.90 & 148 & 6.45 & (+) 111.38 \\
\hline $\begin{array}{l}\text { 5. Passive verb + prepositional phrase fragment e.g. is } \\
\text { seen as }\end{array}$ & 8 & 0.35 & 31 & 1.35 & $(-) 14.49$ \\
\hline 6. Be+noun/adjectival phrase e.g. is a problem & 243 & 10.58 & 85 & 3.70 & $(+) 79.37$ \\
\hline $\begin{array}{l}\text { 7. (Verb phrase })+ \text { that-clause fragment e.g. have shown } \\
\text { that }\end{array}$ & 51 & 2.22 & 50 & 2.18 & $(+) 0.01$ \\
\hline $\begin{array}{l}\text { 8. (Verb/adjective) + to-clause fragment e.g. are } \\
\text { expected to }\end{array}$ & 196 & 8.54 & 206 & 8.97 & $(-) 0.25$ \\
\hline 9. Adverbial clause fragment e.g. as we know & 5 & 0.22 & 3 & 0.13 & $(+) 0.51$ \\
\hline 10. Pronoun/noun phrase + be $(+\ldots)$ e.g. there can be & 77 & 3.35 & 142 & 6.18 & $(-) 19.59$ \\
\hline $\begin{array}{l}\text { 11. 1st/2nd person pronoun }+ \text { VP fragment e.g. I agree } \\
\text { that }\end{array}$ & 260 & 11.32 & 204 & 8.88 & $(+) 6.78$ \\
\hline 12. 3rd person pronoun + VP fragment e.g. this is true & 34 & 1.48 & 34 & 1.48 & $(+) 0.00$ \\
\hline $\begin{array}{l}\text { 13. VP }(\text { Modal }+ \text { V)/ a modal verb phrase e.g. should be } \\
\text { allowed }\end{array}$ & 125 & 5.44 & 187 & 8.14 & $(-) 12.40$ \\
\hline $\begin{array}{l}\text { 14. (connector+) Noun phrase + VP fragment* e.g. } \\
\text { people feel that }\end{array}$ & 127 & 5.53 & 78 & 3.40 & (+) 11.83 \\
\hline $\begin{array}{l}\text { 15. Verb phrase (with non-passive verb)* e.g. can also } \\
\text { be }\end{array}$ & 70 & 3.05 & 136 & 5.92 & $(-) 21.52$ \\
\hline 16. verb phrase with passive verb* e.g. can be shown & 24 & 1.05 & 28 & 1.22 & $(-) 0.31$ \\
\hline 17. other noun phrase expressions e.g. the best solution & 1 & 0.04 & 4 & 0.17 & $(-) 1.93$ \\
\hline Total & 1932 & 84.14 & 1534 & 66.81 & $(+) 45.80$ \\
\hline
\end{tabular}


The most frequently used structures in THAI were anticipatory it + verb/adj at 16.90 per 10,000 words. This was in line with Biber et al. (1999), who found two types of anticipatory lexical bundles. The most frequently used anticipatory lexical bundles are controlled by an adjective phrase, which is more common, while fewer verb phrases are controlled by an adjective phrase (usually in the passive voice). The second and third most frequently used were other prepositional phrase fragments in 13.46, and 1st/2nd person pronoun + VP fragment at 11.32 , respectively. Conversely, the most frequently used structures in NATIVE were(Verb/adjective) + to-clause fragment at 8.97,followed by 1 st/2nd person pronoun $+\mathrm{VP}$ fragment at 8.88 , and VP $($ Modal $+\mathrm{V}) /$ a modal verb phrase at 8.14, respectively.

Table 14

Summary of the structural features of the 4-word stance bundles

\begin{tabular}{|c|c|c|c|c|c|}
\hline 4 -word stance bundles & THAI & $\begin{array}{l}\text { Items per } \\
10,000 \text { words }\end{array}$ & NATIVE & $\begin{array}{l}\text { Items per } \\
10,000 \text { words }\end{array}$ & $\begin{array}{l}\text { LL Ratio } \\
\left(*_{p}<0.05\right)\end{array}$ \\
\hline $\begin{array}{l}\text { 1. Noun phrase with of-phrase fragment e.g. a good } \\
\text { example of }\end{array}$ & 4 & 0.17 & 13 & 0.57 & $(-) 5.02$ \\
\hline $\begin{array}{l}\text { 2. Noun phrase with other post-modifier fragment } \\
\text { e.g. the belief that their }\end{array}$ & 7 & 0.30 & 22 & 0.96 & $(-) 8.15$ \\
\hline $\begin{array}{l}\text { 3. Prepositional phrase with embedded of-phrase } \\
\text { fragment e.g. in terms of the }\end{array}$ & 0 & 0.00 & 0 & 0.00 & 0 \\
\hline $\begin{array}{l}\text { 4. Other prepositional phrase fragments e.g. by the } \\
\text { fact that }\end{array}$ & 63 & 2.74 & 17 & 0.74 & (+) 28.14 \\
\hline $\begin{array}{l}\text { 5. Anticipatory it + verb/adjective phrase e.g. it } \\
\text { could be said, it is clear that }\end{array}$ & 409 & 17.81 & 110 & 4.79 & (+) 183.34 \\
\hline $\begin{array}{l}\text { 6. Passive verb }+ \text { prepositional phrase fragment } \\
\text { e.g. can be seen as }\end{array}$ & 2 & 0.09 & 15 & 0.65 & $(-) 11.25$ \\
\hline $\begin{array}{l}\text { 7. Be }+ \text { noun/adjective phrase e.g. is an issue of, is } \\
\text { not necessary to }\end{array}$ & 48 & 2.09 & 22 & 0.96 & (+) 9.89 \\
\hline $\begin{array}{l}\text { 8. (Verb phrase) + that-clause fragment e.g. can be } \\
\text { seen that }\end{array}$ & 8 & 0.35 & 15 & 0.65 & $(-) 2.16$ \\
\hline $\begin{array}{l}\text { 9. (Verb/adjective) + to-clause fragment e.g. does } \\
\text { not seem to }\end{array}$ & 59 & 2.57 & 44 & 1.92 & (+) 2.19 \\
\hline 10. Adverbial clause fragment e.g. as we know that & 2 & 0.09 & 5 & 0.22 & $(-) 1.33$ \\
\hline $\begin{array}{l}\text { 11. Pronoun/noun phrase }+ \text { be }(+\ldots) \text { e.g. the fact is } \\
\text { that }\end{array}$ & 20 & 0.87 & 71 & 3.09 & (-) 30.31 \\
\hline $\begin{array}{l}\text { 12. 1st/2nd person pronoun + VP fragment e.g. I } \\
\text { agree that we }\end{array}$ & 92 & 4.01 & 76 & 3.31 & (+) 1.53 \\
\hline $\begin{array}{l}\text { 13. 3rd person pronoun }+ \text { VP fragment e.g. this can } \\
\text { be seen }\end{array}$ & 90 & 3.92 & 48 & 2.09 & (+) 12.99 \\
\hline $\begin{array}{l}\text { 14. VP (Modal }+ \text { V)/ a modal verb phrase e.g. } \\
\text { should be able to }\end{array}$ & 127 & 5.53 & 64 & 2.79 & (+) 21.17 \\
\hline Total & 931 & 40.55 & 522 & 22.73 & (+) 116.70 \\
\hline
\end{tabular}

For 4-word stance bundles, the most frequently used structures in THAI were anticipatory it+verb/adj at 17.81 . The second and third most frequently used were VP $($ Modal $+\mathrm{V}) /$ a modal verb phrase, and 1st/2nd person pronoun + VP fragment, respectively. Conversely, the most frequently used structures in NATIVE were anticipatory it+verb/adj at 4.79, which was the first ranked in THAI, followed by 1st/2nd person pronoun+VP fragment, and Pronoun/noun phrase+be $(+\ldots)$, respectively. Both groups employed anticipatory it+verb/adj the most, but Thai learners used it is clear that, it is easy to, it is hard to, it is obvious that, and it is true that more when 
compared to native speakers. Rafiee, Tavakoli, and Amirian's (2011) study explained this phenomenon that target bundles were obviously used by non-native speakers because of exposing to the bundles many times in their prior readings. The shared bundles with previous studies was 'it is difficult to', which occurred in Yang's (2017) study at 125 times in argumentative texts written by Chinese EFL learners.

Table 15

Summary of the structural features of the 3-word engagement bundles

\begin{tabular}{llll}
\hline 3-word Engagement bundles & Structural Patterns & NATIVE & THAI \\
\hline it can be & Anticipatory it + verb/adj & 28 & 58 \\
\hline can be seen & verb phrase with passive verb* & 21 & 22 \\
\hline
\end{tabular}

Table 16

Summary of the structural features of the 4-word engagement bundles

\begin{tabular}{llll}
\hline 4-word Engagement bundles & Structural Patterns & NATIVE & THAI \\
\hline it is important to & Anticipatory it + verb/adj & 8 & 2 \\
\hline it is necessary to & Anticipatory it + verb/adj & 2 & 0 \\
\hline be seen as a & verb phrase with passive verb* & 6 & 0 \\
\hline can be seen as & verb phrase with passive verb* & 5 & 0 \\
\hline can be seen in & verb phrase with passive verb* & 3 & 0 \\
\hline as in the case & Adverbial clause fragment & 4 & 0 \\
\hline as we have seen & Adverbial clause fragment & 2 & 0 \\
\hline that needs to be & Verb phrase (with non-passive verb)* & 4 & 0 \\
\hline
\end{tabular}

For the 3-word engagement bundles, only two bundles were found in both corpora: 'it can be', and 'can be seen.' The rankings between two corpora were the same, but there were differences in terms of frequency. 'it can be' was discovered more frequently in THAI corpus.

Examples below showed how native speakers used these bundles in their corpus.

(1) Normally, the couple have to come up with the money themselves and perhaps it can be even said that they are buying a child. Money which perhaps some couples don't have. (NATIVE-alevels8ICLE-ALEV-0007.8)

(2) Violence on television can be seen throughout the many channels that cable has to offer. (NATIVE-USARGICLE-US-SCU-0007.3)

For the 4-word engagement bundles, there were a variety of patterns in the NATIVE corpus. Also, 'it is important to' was used the most at eight times in NATIVE while this bundle was only found twice in THAI. However, there was only one 4-word engagement bundle found in the THAI corpus. According to Table 16, in the NATIVE corpus, a variety of bundles were used, whereas only one type of 4-word engagement bundle was evident in THAI. It meant that Thai learners should practice more in this area in order to interact with their readers in the texts.

The instance below displayed how native speakers used the bundle in the corpus.

(3) It is important to remember that while coming to a solution, the children's best interests are always in mind. (NATIVE-USARGICLEUSMRQ0024.1) 


\section{Pedagogical Implications}

The results of this study may be beneficial to EFL stakeholders such as learners and teachers. First, for learners, the findings may serve as a useful guideline, especially for those who want to learn how to include interactional markers in argumentative writing to interact with readers effectively. The results of this research may also facilitate the identification, comprehension and appropriate use of interactional markers in academic writing. Therefore, learners could reap the benefits from the findings since they reflect authentic language used by native speakers. The results could also be useful in English language teaching by virtue of making teachers aware of the linguistic elements that influence learners' writing ability. Moreover, teachers, as well as those who are interested in developing English teaching methods in academic writing classes, especially argumentative writing, may benefit from the observations pertaining to the ways native speakers of English and non-native speakers use language, enabling them to select suitable teaching techniques and methods to enhance their students' writing skill.

Through the appropriate use of the target items in the argumentative essays, it could benefit the writers to interact with their readers with their readers in an effective way. Their texts would become more convincing texts and able to persuade the readers to believe in the arguments of the text written. Therefore, in order to increase the efficiency of the use of metadiscourse markers and participant-oriented bundles in argumentative texts for learners, language teachers should encourage them to employ the target items in a wider range via using a corpus-based materials or tasks in order to decrease redundancies and repetitions in the texts.

\section{Limitations and Recommendations for Future Research}

There are three important limitations. First, the data came from only one university in the THAI corpus and it was an international program, so it represented only the performance of the students from this university. Therefore, future research should concern the varieties of samples. Moreover, the NATIVE corpus contained only argumentative essays written by American and British university students, limiting the generalizability of the findings. As the results may not be applicable to other Englishes in the Inner Circle, such as New Zealand English, Canadian English and Australian English, future research should use additional corpora in other contexts as well as other methodologies to investigate the potential linguistic changes. Third, since Thai learners who were studying English in an international university in Thailand were chosen as the EFL group, the results may not be generalizable to other EFL contexts, neither in the same country nor in other countries such as China, Korea, and Japan due to considerable contextual differences. Thus, it is suggested that a greater variety of EFL learners be included in future research to improve the generalizability.

\section{CONCLUSION}

Overall, the comparisons in the present study between the two corpora revealed both similarities and differences with respect to metadiscourse markers and participantoriented bundles. However, the differences between the frequency counts of the metadiscourse markers and participant-oriented bundles used in NATIVE and THAI suggests that the writers had dissimilar preferences with regard to writing argumentative 
texts. Based on the analysis of each type of the interactional metadiscourse markers and participant-oriented bundles, the results imply that both groups preferred to interact with their readers in different ways. The reasons for this may be related to genre, linguistic proficiency, sociocultural perspective, or even students' L1 background.

\section{REFERENCES}

Abdi, R. (2002). Interpersonal metadiscourse: An indicator of interaction and identity. Discourse Studies, 4(2), 139-145.

Abdullah, A., \& Pederson, P. B. (2009). Understanding multicultural Malaysia delights, puzzles and irritations. Pearson Malaysia Sdn. Bhd.

Ädel, A., \& Erman, B. (2012). Recurrent word combinations in academic writing by native and non-native speakers of English: A lexical bundles approach. English for specific purposes, 31(2), 81-92.

Allen, D. (2009). Lexical bundles in learner writing: An analysis of formulaic language in the ALESS learner corpus. Komaba Journal of English Education, 1, 105-127.

Altenberg, B. (1998). On the phraseology of spoken English: The evidence of recurrent word-combinations. na.

Anthony, L. (2014). AntConc (Version 3.2.4w) [Computer Software]. Tokyo, Japan: Waseda University. Available from http://www.laurenceanthony.net/

articles. English for specific purposes, 20(3), 207-226.

Beauvais, P. J. (1989). A speech act theory of metadiscourse. Written communication, 6(1), 11-30.

Biber, D., \& Finegan, E. (1989), Styles of stance in English: Lexical and grammatical marking of evidentiality and affect. Text, 9: 93-125.

Biber, D., Conrad, S., \& Cortes, V. (2004). If you look at...: Lexical bundles in university teaching and textbooks. Applied linguistics, 25(3), 371-405.

Biber, D., Johansson, S., Leech, G., Conrad, S., \& Finegan, E. (1999). Longman grammar of written and spoken English. Harlow: Longman.

Byrd, P., \& Coxhead, A. (2010). On the other hand: Lexical bundles in academic writing and in the teaching of EAP. University of Sydney Papers in TESOL, 5(5), 31-64.

Chan, S., \& Tan, H. (2010). Extracting and comparing the intricacies of metadiscourse of two written persuasive corpora. International Journal of Education and Development using ICT, 6(3), 124-146.

Chen, Y. H., \& Baker, P. (2010). Lexical bundles in L1 and L2 academic writing. Language Learning \& Technology, 14(2), 30-49.

Cortes, V. (2001). Lexical bundles in published and student disciplinary writing: Examples from history and biology. V. Cortes. Iowa State University, Department of English, 203 Ross Hall, Ames, IA 50014, USA, 400.

Cortes, V. (2002). Lexical bundles in Freshman composition. Using corpora to explore linguistic variation, 9, 131-145. 
Cortes, V. (2006). Teaching lexical bundles in the disciplines: An example from a writing intensive history class. Linguistics and education, 17(4), 391-406.

Cortes, V. (2013). The purpose of this study is to: Connecting lexical bundles and moves in research article introductions. Journal of English for academic purposes, 12(1), 33-43.

Crismore, A. (1989). Talking with readers: Metadiscourse as rhetorical act (Vol. 17). Peter Lang Pub Incorporated.

Getkham, K. (2016). Authorial Stance in Thai Students' Doctoral Dissertation. English Language Teaching, 9(3), 80-95.

Gholami, J., Nejad, S. R., \& Pour, J. L. (2014). Metadiscourse markers misuses; a study of EFL learners' Argumentative Essays. Procedia-social and behavioral sciences, 98, 580-589.

Halliday, M.A.K. (1994). An Introduction to Functional Grammar. 2nd edition. London: Edward Arnold.

Harris, Z. S. (1959). The transformational model of language structure. Anthropological Linguistics, 27-29.

Hayisama, F., Shah, M. I. A., \& Adnan, W. N. A. W. (2019). Rhetorical style across cultures: an analysis of metadiscourse markers in academic writing of Thai and Malaysian students. LSP International Journal, 6(1).

Hinkel, E. (2002). Second language writers' text: Linguistic and rhetorical features. Routledge.

Hu, C., \& Li, Y. (2015). Discourse Connectives in L1 and L2 Argumentative Writing. Higher Education Studies, 5(4), 30-41.

Hunston, S., \& Thompson, G. (Eds.). (2000). Evaluation in text: Authorial stance and the construction of discourse: Authorial stance and the construction of discourse. Oxford University Press, UK.

Hyland, K. (1990). A genre description of the argumentative essay. RELC journal, 21(1), 66-78.

Hyland, K. (1998). Persuasion and context: The pragmatics of academic metadiscourse. Journal of pragmatics, 30(4), 437-455.

Hyland, K. (1999). Talking to students: Metadiscourse in introductorycoursebooks. English for specific purposes, 18(1), 3-26.

Hyland, K. (2001). Humble servants of the discipline? Self-mention in research

Hyland, K. (2002). Directives: Argument and engagement in academic writing. Applied linguistics, 23(2), 215-239.

Hyland, K. (2004). Disciplinary interactions: Metadiscourse in L2 postgraduate writing. Journal of second language writing, 13(2), 133-151.

Hyland, K. (2005). Metadiscourse: Exploring interaction in writing. Bloomsbury Publishing. 
Hyland, K. (2008a). As can be seen: Lexical bundles and disciplinary variation. English for Specific Purposes, 27, 4-21.

Hyland, K. (2008b). Academic clusters: Text patterning in published and postgraduate writing. International Journal of Applied Linguistics, 18(1), 41-62.

Hyland, K. (2008c). Persuasion, interaction and the construction of knowledge: Representing self and others in research writing. International Journal of English Studies, 8(2), 1-23.

Hyland, K. (2012). Bundles in academic discourse. Annual review of applied linguistics, 32, 150-169.

Hyland, K., \& Tse, P. (2004). Metadiscourse in academic writing: A reappraisal. Applied linguistics, 25(2), 156-177.

Incharoensak, M. C. (2018). Hedges and boosters in US college application essays: A corpus-based comparative study between US middle and US top college application essays (Doctoral dissertation, Thammasat University).

Jalali, H., Rasekh, A.E., \& Rizi, M.T. (2008). Lexical bundles and intradisciplinary variation: The case of applied linguistics. International Journal of Language Studies, 2 (4), 447- 484

Kitjaroonchai, N. (2019). Stance and Engagement Use in a Timed Argumentative Essay by Asian First-Year University Students Studying English as a Foreign Language. HUMAN BEHAVIOR, DEVELOPMENT and SOCIETY, 20(3), 105-115.

Lee, J. J., \& Deakin, L. (2016). Interactions in L1 and L2 undergraduate student writing: Interactional metadiscourse in successful and less-successful argumentative essays. Journal of second language writing, 33, 21-34.

Lee, J. J., \& Subtirelu, N. C. (2015). Metadiscourse in the classroom: A comparative analysis of EAP lessons and university lectures. English for Specific Purposes, 37, 5262.

Mahmood, R., Javaid, G., \& Mahmood, A. (2017). Analysis of Metadiscourse Features in Argumentative Writing by Pakistani Undergraduate Students. International Journal of English Linguistics, 7(6), 78-87.

Martin, J. (2000). Beyond exchange: Appraisal systems in English. Evaluation in text.

Muslu, M. (2018). Use of Stance Lexical Bundles by Turkish and Japanese EFL Learners and Native English Speakers in Academic Writing. Gaziantep University Journal of Social Sciences, 17(4), 1319-1336.

Pang, P. (2009). A study on the use of four-word lexical bundles in argumentative essays by Chinese English-majors: A comparative study based on WECCL and LOCNESS. Teaching English in China, 32(3), 25-4.

Paquot, M., \& Granger, S. (2012). Formulaic language in learner corpora. Annual Review of Applied Linguistics, 32, 130-149.

Petchkij, W. (2019). Explicit Teaching of Hedges: Bringing Hedging in Academic Writing into the Thai EFL Classroom. Electronic Journal of Foreign Language Teaching, 16(1), 95-113. 
Prasithrathsint, A. (2015). Linguistic markers and stylistic attributes of hedging in English academic papers written by native and non-native speakers of English. Manusya: Journal of Humanities, 18(1), 1-22.

Prommas, P., \& Sinwongsuwat, K. (2014). A comparative study of discourse connectors used in argumentative compositions produced by Thai EFL learners and English-native speakers.

Rafiee, M., Tavakoli, M., \& Amirian, Z. (2011). Structural analysis of lexical bundles across two types of English newspapers edited by native and non-native speakers. Modern Journal of Applied Linguistics, 3(2), 218-236.

Reid, J. M. (1988). The process of composition (Vol. 1). Prentice Hall.

Richards, J. C., \& Schmidt, R. (2002). Longman dictionary of applied linguistics and language teaching. Harlow, UK: Longman.

Siribud, S. (2016). Authorial stances in classroom speeches: A corpus-based study. PASAA PARITAT, 31, 141-162.

Sukhanindr, M. (2008). Hedging in research articles about English language teaching written by Thai and native speakers of English (Unpublished Master's Thesis), Kasetsart University, Bangkok, Thailand.

Suksawas, W. (2016). Gender-based study of Thai learners' metadiscourse in writing for journalism. Naresuan University, 1-15.

Suntara, W., \& Chokthawikit, S. (2018). Interactional Metadiscourse in Research Article Abstracts: An Analysis from Public Health Journals. Language and Linguistics, 36, 31-52.

Thompson, G., \& Thetela, P. (1995). The sound of one hand clapping: The management of interaction in written discourse. Text-Interdisciplinary Journal for the Study of Discourse, 15(1), 103-128.

Wang, L., \& Zhang, Y. (2006). A corpus-based study on chunks in English argumentative writing of Chinese EFL learners. Computer-assisted Foreign Language Education, 4, 36-41.

Wei, Y., \& Lei, L. (2011). Lexical bundles in the academic writing of advanced Chinese EFL learners. RELC journal, 42(2), 155-166.

Wijitsopon, R. (2017). Collocations and local textual functions of quantifiers in learner English essays. Linguistic Research, 34(1), 1-49.

Wongwiwat, T. (2016). Move analysis and lexical bundle analysis of conference abstracts: a case study of Thailand TESOL international conferences (doctoral dissertation, Thammasat University).

Yang, Y. (2017). Lexical bundles in argumentative and narrative writings by Chinese EFL learners. International Journal of English Linguistics, 7(3), 58-69.

Zhang, J. (2015). An analysis of the use of demonstratives in argumentative discourse by Chinese EFL learners. Journal of Language Teaching and Research, 6(2), 460-465 